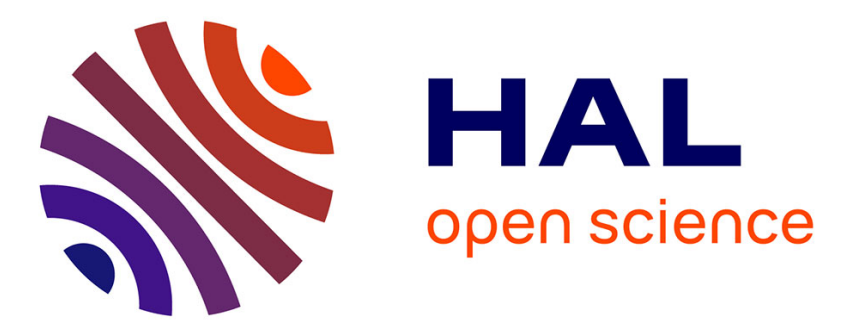

\title{
The Moka cattle, an element of the Reunion Island heritage to preserve
}

\author{
Olivia Fontaine, Jean Philippe J. P. Choisis, Michel Naves Navès
}

\section{To cite this version:}

Olivia Fontaine, Jean Philippe J. P. Choisis, Michel Naves Navès. The Moka cattle, an element of the Reunion Island heritage to preserve. Advances in Animal Biosciences, 2010, 1 (2), pp.479-480. 10.1017/S2040470010000993 . hal-02656190

\section{HAL Id: hal-02656190 https://hal.inrae.fr/hal-02656190}

Submitted on 29 May 2020

HAL is a multi-disciplinary open access archive for the deposit and dissemination of scientific research documents, whether they are published or not. The documents may come from teaching and research institutions in France or abroad, or from public or private research centers.
L'archive ouverte pluridisciplinaire HAL, est destinée au dépôt et à la diffusion de documents scientifiques de niveau recherche, publiés ou non, émanant des établissements d'enseignement et de recherche français ou étrangers, des laboratoires publics ou privés. 


\title{
Material \& methods
}

Male agoutis were dissected for macro-anatomy description and tissue samples taken for hematoxylin-eosin histological analysis. Various electrical stimulations were applied from an electro-ejaculator to identify a protocol for electro-ejaculation of the agouti. Three (3) available substances (UHT Milk, pasteurized and un-pasteurized coconut water) were evaluated as semen extenders for extension and storage of the agouti's semen.

\section{Results/Discussion}

The male agouti had a U-shaped penis and a paired lateral penile cartilage which were only identified in $D$. leporina.

Electro-ejaculation success improved from $30 \%$ (initially) to $75 \%$ when xylazine (40 mg/kg live body-weight) was used as an anesthetic. This latter success was attributed to the muscle relaxing properties of xylazine. Mean spermatozoa concentration, motility and percentage abnormalities were $106.7 \pm 31.1 \times 10^{6}$ spermatozoa $/ \mathrm{mL}, 50.44 \pm 4.44 \%$, and $35.14 \pm 2.76 \%$, respectively during the development of the electro-ejaculation protocol. However, in later trials the mean spermatozoa concentration improved to $431 \pm 180$ and $306.6 \pm 64.9 \times 10^{6}$ spermatozoa/mL during two continuous experiments. Eleven (11) spermatozoa morphologies were identified. The majority (68.5\%) of spermatozoa showed no known defects and was considered normal. Mean lengths for head, mid piece, tail and total length of the agouti spermatozoa were $5.23 \pm 0.04 \mu \mathrm{m}, 5.18 \pm 0.08 \mu \mathrm{m}, 37.52 \pm 0.24 \mu \mathrm{m}$ and $47.96 \pm 0.25 \mu \mathrm{m}$, respectively. There was a direct relationship between fructose concentration in agouti ejaculate and abnormal spermatozoa.

Agouti ejaculates extended with UHT milk, diluted to a spermatozoa concentration of $100 \times 10^{6}$ spermatozoa/mL and filled in $0.25 \mathrm{~mL}$ vials produced the best results $(P<0.05)$, for motility $\%$ after storage at $5^{\circ} \mathrm{C}$ for five days.

\section{Conclusion}

It was concluded that the survival of spermatozoa in a given volume $(0.25 \mathrm{~mL})$ of extended agouti semen stored at $5^{\circ} \mathrm{C}$ is dependant on the stored spermatozoa concentration.

\section{The Moka cattle, an element of the Reunion Island heritage to preserve}

\author{
Olivia Fontaine ${ }^{1 \dagger}$, Jean-Philippe Choisis ${ }^{2}$ and Michel Naves ${ }^{3}$ \\ ${ }^{1}$ CIRAD, UR 18, 97410 Saint-Pierre, France, ${ }^{2}$ INRA UMR 1201 Dynafor, F- 31326 Castanet-Tolosan, France; ${ }^{3}$ INRA UR143 URZ, 97170 Petit Bourg, France
}

\section{Introduction}

To satisfy the needs in animal pulling, in particular for cane sugar transport, cattle were introduced onto the Reunion Island during the 18th and 19th centuries. The animals originated from Madagascar and West Africa. With the mechanization of transport, the use of draught animals was gradually reduced while choices were made to develop a meat production sector with "improved" breeds imported from the mother country. Consequently, the local "Moka" population became residual. Neither conservation action nor recognition has been undertaken for this population which does not benefit from an official status, although rare and at risk. Some breeders preserving this heritage, created an association in 2006 whose general purpose is to preserve and promote the breed, and to defend the interests of Moka breeders. In order to help the breeders in their initiative, we undertook a first characterization study of the Moka breed.

\section{Material and methods}

Because of the lack of data on this population, we took action in order to complete a recognition file. Firstly, we explored bibliographical sources and collected information among experts in order (I) to provide information on the history, the situation, uses, animal performance and (II) to carry out an exhaustive inventory of the breeders owning animals from this population. Secondly, eleven identified herds were surveyed to characterize their structure and the main breeding operations. These site visits enabled us to locate animals described as the Moka type according to the view of breeders. Thirty-three animals were the subject of a phenotypical description, linear measurements (height at withers, rump width, thoracic perimeter) and weight. The genetic characterization of the breed was also carried out. Blood samples were taken from 38 animals, between November 2005 and March 2006 for analysis of the 16 microsatellite markers used for parentage testing in France. Different datasets were constituted and statistically analysed according to the type of data.

\section{Results}

The breeding practices of the surveyed herds differed little between farms. Moka herds are bred on very poor savannahs, almost without supplementation. They are kept for their hardiness, their capacity to withstand very strong seasonal variations in forage availability. These

\footnotetext{
† E-mail: olivia.fontaine@cirad.fr
} 
variations of forage resources lead to a natural season of calving from December to March, when savannahs are green and the grass is of good quality. The mating season extends from mid-February to June, with several males in the herd. According to the breeders, the Moka cows have good reproductive capacity and great longevity: they produce one calf per year, on average, along a productive life which can last 15 years. Calving is easy, without supervision or intervention. Marketing is done mostly by direct sale of live or slaughtered animals. Threehundred twenty-five animals were listed on the survey, on 11 farms, with an average of 30 animals per herd.

Thirty-three animals typed as Moka by their owners were the subject of a phenotypical description and measurements. The mean value for the thoracic perimeter, the height at withers and the rump width are respectively $162 \pm 15.2 \mathrm{~cm}, 116 \pm 8.3 \mathrm{~cm}$ and $120 \pm 17.6 \mathrm{~cm}$; the mean liveweight of males and females are $430 \pm 85 \mathrm{~kg}$ and $340 \pm 45 \mathrm{~kg}$ respectively. These results constitute the initial values of a zootechnical description of the breed. They show the underaverage development of the animals, which can be qualified as medium sized. A photographic database of individual animals was created and could be used for the definition of the standard of the breed.

The genetic analysis showed that the population presents a good allelic richness (6.7 alleles/locus) and genetic diversity (measured by an unbiased heterozygocity of 0.75$)$, and a low estimated consanguinity (3.3\%). Some specific features have been identified, such as the presence of zebu specific alleles, but few admixtures of taurine cattle. The relationship of this breed with African breeds, especially from Madagascar, or with European or Creole cattle will be studied in more detail in the future.

\title{
Conclusion
}

This first approach provided initial results on breeding systems and the Moka cattle population to build a file of national recognition. It also put forward the many constraints with which breeders are confronted, such as land constraints and transmission problems. Beyond the difficulties of organization of these breeding activities, which are not part of official programmes, it seems to us that the present breeding model will not be able to continue because of the disappearance of savanna following rapid urbanization. So, the question is the following, is conservation of this breed anyway compatible with a less pastoral breeding model? However, this breed shows some original characteristics that make it a valuable genetic resource for tropical environments. The presence of a selection signature for adaptation to tropical constraints that could be present in this breed will be investigated.

\section{Intensive production system of collared peccary (Pecari tajacu) in Brazilian Amazon}

\author{
Natália Inagaki de Albuquerque ${ }^{1}$, Diva Anélie Guimarães ${ }^{2 \dagger}$, Hilma Lúcia Tavares Dias ${ }^{2}$, \\ Yvonnick Le Pendu ${ }^{3}$, Priscila Reis Kahwage ${ }^{1}$ and Alexandre Rossetto Garcia ${ }^{1}$
}

\footnotetext{
${ }^{1}$ Embrapa Amazônia Oriental, Tv. Enéas Pinheiro S/N, Marco, CEP 66095-100, Belém-Pará-Brasil, Brasil; ${ }^{2}$ Universidade Federal do Pará, Laboratório de Reprodução Animal, Instituto de Ciências Biológicas, Belém-Pará-Brasil, Brasil; ${ }^{3}$ Universidade Estadual de Santa Cruz, Departamento de Ciências Biológicas, Ilhéus-Bahia-Brasil, Brasil
}

\section{Introduction}

Wild game meat is one of the most important feed resources to rural communities that live in the tropical forest, however, in Brazil hunting is an illegal activity. Strategies are required to establish policies addressed to this type of activity. They must be based on adopting sustainable management programs and include elements to conserve target species of illegal trade and ensure legal means of access to a large portion of the Amazonian population, who have strong cultural ties with these resources. The collared peccary (Pecari tajacu) is one of the most appreciated game meats in the Brazilian Amazon. The general purpose of our work was to study the captive production system of collared peccary to obtain a viable production for subsistence or commercialization. This study describes the main results of a captive management program on collared peccary in the state of Pará, Brazil.

\section{Material and methods}

The behavioural, reproductive, sanitary and nutritional aspects of collared peccary were studied in the last 10 years (between 1999 and 2009) on an experimental farm of collared peccary in Embrapa (Belém, Pará, Brazil, $01^{\circ} 24^{\prime} \mathrm{S} ; 48^{\circ} 20^{\prime} \mathrm{W}$ ). The climate of this region is equatorial with an average annual temperature of $27^{\circ} \mathrm{C}$, and an average relative humidity of $80 \%$. All reproductive groups were formed by a $1: 3$ male to female rate ratio, individually raised in paddocks of $21 \mathrm{~m}^{2}, 36 \mathrm{~m}^{2}$ and a single large floor paddock of $450 \mathrm{~m}^{2}$. All animals were maintained under natural lighting conditions. Paddock temperatures ranged from $22^{\circ}$ to $32^{\circ} \mathrm{C}$. The caloric and protein supply per animal and per day were $2500 \mathrm{kcal}$ and $14 \%$, respectively. Water was always available.

\footnotetext{
† E-mail: diva@ufpa.br
} 